\title{
TOKSISITAS DAN TINGKAT ABSORBSI INSEKTISIDA ENDOSULFAN DAN KLORPIRIFOS PADA IKAN NILA (Oreochromis niloticus) DI LABORATORIUM
}

\author{
Sutrisno*), Santosa Koesoemadinata"), dan Ongko Praseno")
}

\begin{abstract}
ABSTRAK
Pengujian toksisitas letal dan tingkat absorbsi insektisida endosulfan dan klorpirifos pada ikan nila (Oreochormis niloticus) dilakukan di laboratorium, untuk mengetahui potensi pengaruh negatif insektisida tersebut terhadap budi daya ikan. Toksisitas letal kedua jenis insektisida ditentukan dengan metode uji toksisitas statis yang telah distandarisasikan selama waktu dedah 96 jam. Sebagai ikan uji digunakan benih ikan nila (bobot rata-rata 2,5 g/ekor). Hasil percobaan dinyatakan dalam nilai LC $_{50}$ (Median Lethal Concentration). Toksisitas subletal dan tingkat akumulasi insektisida dalam tubuh ikan ditentukan dengan mendedahkan ikan uji (bobot ratarata $1,5 \mathrm{~g}$ ) dalam 3 tingkat konsentrasi subletal insektisida selama satu bulan. Pada akhir percobaan pertumbuhan ikan uji dan tingkat residu insektisida dalam tubuh ikan dan larutan uji dievaluasi. Tingkat absorbsi insektisida dinyatakan dalam persentase residu insektisida dalam tubuh ikan dari konsentrasi nominal dalam larutan uji. Hasil percobaan menunjukkan bahwa insektisida endosulfan dan klorpirifos berdaya racun sangat tinggi pada ikan nila, dengan nilai $\mathrm{LC}_{50^{-}} 96 \mathrm{jam}$ masing-masing $0,0127 \mathrm{mg} / \mathrm{L}$ dan 0,245 mg/L. Tingkat absorbsi kedua insektisida tersebut ke dalam tubuh ikan pada tingkat konsentrasi subletal (masing-masing 0,005 mg/L dan $0,1 \mathrm{mg} / \mathrm{L}$ ) selama waktu dedah satu bulan adalah $22 \%$.
\end{abstract}

ABSTRACT: Toxicity and bio accumulation rate of the insecticides endosulfan and chlorpyrifos to the nile tilapia (Oreochromis niloticus) in the laboratory. By: Sutrisno, Santosa Koesoemadinata, and Ongko Praseno

\begin{abstract}
Laboratory experiments on the lethal toxicity and the bio accumulation rate of the insecticide endosulfan and chlorpyrifos to the nile tilapia (Oreochromis niloticus) have been conducted to define the potential negative effects of these chemicals to fish culture. Lethal toxicity was measured using a standardised static toxicity test method, for a period of 96 hours. Nile tilapia fingerlings ( $2.5 \mathrm{~g}$ average weight) were used as test fish. Results of the test was presented as $L C_{50}$ (the Median Lethal Concentration) values. The sublethal toxicity and the absorbtion rate of the insecticides were determined by exposing test fishes (1.5 g average weight) to three levels of sublethal concentrations of both insecticides for a period of one month. Fish growth rates and residue levels of the insecticides in the fish body and in the dilution water were evaluated at the termination of the test. Absorbtion rate was presented as percentage of the residue of the insecticides in fish from their respective nominal concentrations in the dilution water. Results of the experiments showed that the insecticides endosulfan and chlorpyrifos were both extremely toxic to the nile tilapia, producing $96 \mathrm{hrs}-\mathrm{LC}_{50}$ of $0.0127 \mathrm{mg} / \mathrm{L}$ and $0.245 \mathrm{mg} / \mathrm{L}$, respectively. Absorbtion rates the two insecticides at sublethal concentration levels of $0.005 \mathrm{mg} / \mathrm{L}$ and $0.1 \mathrm{mg} / \mathrm{L}$, respectively, amounted to $22 \%$
\end{abstract}

KEYWORDS: insecticide, toxicity, bio accumulation, freshwater fish, tilapia

\section{PENDAHULUAN}

Pernakaian insektisida di bidang pertanian, kehutanan, dan kesehatan secara potensial dapat menimbulkan dampak negatif pada usaha perikanan tangkap maupun usaha perikanan budi daya air tawar. Pengaturan dan upaya penanganan masalah lingkungan ini menghadapi kendala utama karena tidak tersedianya data dan informasi yang lengkap tentang pengaruh bahan-bahan pencemar tersebut terhadap jenisjenis ikan dan biota akuatik lainnya di Indonesia.
Memburuknya kualitas lingkungan akuatik perikanan air tawar karena pencemaran oleh insektisida menyebabkan kematian ikan serta penurunan produksi maupun kualitas hasil perikanan. Hasil pengujian toksisitas akut 79 formulasi pestisida padi sawah yang didaftarkan di Indonesia, menunjukkan bahwa $17,7 \%$ bahan aktif pestisida berdaya racun tinggi pada ikan (Koesoemadinata, 1980). Upaya pelestarian ekosistem akuatik dan sumber daya perikanan air tawar dari dampak negatif insektisida, perlu ditunjang oleh data dan informasi toksikologi akuatik 
yang mencakup toksisitas, daya persistensi, serta tingkat absorpsi insektisida di ekosistem perairan maupun dalam tubuh ikan (Koesoemadinata, 1985). Data dan informasi tersebut sangat kurang atau bahkan tidak tersedia, sehingga seringkali perlu mengacu pada data dari luar negeri yang umumnya tidak atau kurang relevan dengan kondisi ekologis di Indonesia. Residu insektisida dapat mencemari lingkungan akuatik perikanan melalui aplikasi langsung maupun melalui pembuangan/ pencucian (run-off) dari wilayah aplikasinya di dataran tinggi. Kasus kontaminasi akibat pemakaian insektisida endosulfan di sawah terjadi pada tahun 1969, yang telah menyebabkan kerugian besar kepada petani ikan di DAS Brantas, Jawa Timur (Gorbach et al., 1971a dan 1971b). Kasus ini merupakan kasus pencemaran insektisida dalam skala luas yang klasik di Indonesia. Kasus-kasus serupa dalam skala lebih kecil sering terjadi.

Endosulfan $(1,4,5,6,7,7$-heksakloro-9,9,10trinorborn-5-en-2,3-ylinbismetilin) sulfit, adalah satusatunya bahan aktif insektisida organoklorin yang terdaftar dan masih banyak digunakan di bidang pertanian di negara ini. Toksisitas akut endosulfan pada jenisjenis ikan di Amerika Serikat adalah 0,2-1,8 mg/L, (Macek et al., 1969; EPA, 1980; Ananda et al., 1981).

Klorpirifos, 0,0-dietil 0-(3,5,6-trikloro-2-piridil) fosforotioat, adalah senyawa bahan aktif insektisida golongan organofosforotioat yang berspektrum lebar dan banyak digunakan di bidang pertanian. Toksisitas akut klorpirifos dapat mematikan ikan pada kosentrasi 2,4-280 mg/L (Macek et al., 1969; EPA, 1980; Ananda et al.,1981). Toksisitas subakut atau kronis kedua jenis insektisida tersebut, khususnya terhadap biota akuatik di Indonesia, belum banyak diketahui. Toksisitas subakut adalah pengaruh jangka panjang yang dapat menyebabkan kerusakan morfologis maupun fisiologis pada ikan (Holcombe et al.,1982; Murty \& Priyamanvada, 1982).

Dalam penelitian ini dilakukan serangkaian percobaan toksikologi akuatik insektisida endosulfan dan klorpirifos terhadap ikan nila (Oreochromis niloticus), salah satu jenis air tawar yang penting di negara ini. Penelitian mencakup percobaan toksisitas letal, toksisitas subletal, dan tingkat absorbsi insektisida-insektisida tersebut pada ikan nila. Dari hasil percobaan ini diperoleh data toksisitas yang dapat digunakan sebagai acuan kebijakan pemakaian pestisida di bidang pertanian dan bagi penentuan baku mutu perairan perikanan.

\section{BAHAN DAN METODE}

\section{Penentuan toksisitas letal insektisida}

Pengujian dilakukan dengan metode uji toksisitas statis dengan menggunakan bak akuarium kaca.
Metode ini telah dibakukan secara teknis maupun prosedural oleh organisasi- organisasi internasional seperti FAO (1987) dan OECD (1992). Sebagai bahan uji dipakai dua formulasi dagang insektisida dengan kandungan bahan aktif $350 \mathrm{~g}$ endosulfan/L dan $200 \mathrm{~g}$ klorpirifos/L. Benih ikan nila berukuran seragam dengan bobot rata-rata 2,5 g per ekor digunakan sebagai hewan uji. Jumlah ikan per konsentrasi 10 ekor/20 L (>1 g bobot ikan/L. Iarutan uji). Pengujian dilakukan terhadap 5 tingkat konsentrasi insektisida yang dipersiapkan dalam deret logaritmik, masingmasing dalam 3 ulangan. Deretan konsentrasi pada pengujian endosulfan adalah : 0,$01 ; 0,013 ; 0,015$; 0,017 ; dan $0,02 \mathrm{mg} / \mathrm{L}$, sedang untuk pengujian klorpirifos adalah : 0,$1 ; 0,24 ; 0,32 ; 0,42 ; 0,56$; dan $0,75 \mathrm{mg} / \mathrm{L}$. Konsentrasi-konsentrasi tersebut dipersiapkan berdasarkan bahan aktif insektisida Waktu pengujian toksisitas letal ini adalah 4 hari. Kematian ikan dicatat secara kumulatif setiap 24 jam sekali. Data mortalitas ikan tersebut kemudian dianalisis secara statistik dengan metode probit (Finney,1971), untuk mendapatkan nilai-nilai konsentrasi paroh yang mematikan atau Median Lethal Concentration ( $\mathrm{LC}_{50}$ ) dengan nilai-nilai intervainya pada limit kepercayaan 50\%, untuk waktu dedah 24, 48,72 , dan 96 jam

\section{Penentuan toksisitas subletal dan tingkat absorbsi residu insektisida}

Percobaan biologis ini dilakukan di laboratorium dalam bak-bak serat kaca berukuran $50 \times 40 \times 40$ $\mathrm{cm}^{3}$ (px|xt), dengan volume larutan uji 50/L bak. 20 ekor benih ikan nila (bobot rata-rata 1,50 g/ekor) didedahkan pada 3 tingkat konsentrasi subletal insektisida masing-masing dalam 3 ulangan, selama satu bulan. Konsentrasi subletal endosulfan yang digunakan adalah; 0,001; 0,005; dan 0,01 mg/L., sedang konsentrasi klorpirifos adalah 0,05; 0,1; dan $0,15 \mathrm{mg} / \mathrm{L}$. Untuk menjaga agar tingkat konsentrasi tersebut relatif konstan larutan uji diganti setiap dua hari sekali dengan larutan baru dengan konsentrasi yang sama. Percobaan dilakukan dengan rancangan acak lengkap. Selama percobaan, ikan uji diberi pakan dengan ransum 30\%-40\% per bobot ikan per hari. Bobot individu ikan uji ditimbang pada awal dan pada akhir percobaan untuk menentukan pertumbuhan ikan pada tiap perlakuan selama waktu dedah satu bulan. Data pertumbuhan ikan dianalisis secara statistik dengan sidik ragam rancangan acak lengkap dilanjutkan dengan uji BNT pada taraf $1 \%$ dan $5 \%$.

Pada akhir percobaan dilakukan analisis residu insektisida terhadap sampel larutan uji dan ikan uji. Analisis residu dilakukan dengan menggunakan alat kromatografi gas atau GC (Gas Chromatography). Dengan mengggunakan data residu tersebut ditentu- 
kan tingkat absorbsi insektisida yakni persentase konsentrasi residu dalam jaringan tubuh ikan dari konsentrasi nominal larutan insektisida yang diuji (Spacie \& Hamelink, 1985).

\section{HASIL DAN BAHASAN}

Hasil percobaan toksisitas letal insektisida endosulfan dan klorpirifos terhadap ikan nila tertera pada Tabel 1. Semua data hasil percobaan toksikologi menguraikannya menjadi endosulfan sulfat yang masih toksik pada ikan (Anon., 1980; Rao et.al,1981).

Menurut Rivai et al. (1976), LC L0 $_{5}-48$ jam formulasi klorpirifos untuk ikan nila adalah 114 (84-156) mg/L dan LC Lo $_{50} 48$ jam. Barron \& Woodburn (1995) menyatakan bahwa berdasarkan data $\mathrm{LC}_{50}$ insektisida ini berdaya racun sangat akut terhadap ikan air tawar maupun ikan air asin pada kisaran konsentrasi 0,5 dan $1.000 \mathrm{mg} / \mathrm{L}$.

Tabel 1. Toksisitas letal ( $\left.\mathrm{LC}_{50}\right)$ insektisida endosulfan dan klorpirifos pada ikan nila (Oreochromis niloticus) Table 1. The lethal toxicity (LC50) of the endosulfan insecticide and chlorpyrifos to the nile tilapia (Oreochromis niloticus)

\begin{tabular}{lccc}
$\begin{array}{l}\text { Insektisida } \\
\text { Insecticide }\end{array}$ & $\begin{array}{l}\text { Waktu dedah (jam) } \\
\text { Exposure period (hour) }\end{array}$ & $\begin{array}{l}\mathrm{LC}_{50}(\mathrm{mg} / \mathrm{L}) \\
\mathrm{LC}_{50}(\mathrm{mg} / \mathrm{L})\end{array}$ & $\begin{array}{c}\text { Limit kepercayaan 95\% } \\
95 \% \text { Confidence limits }\end{array}$ \\
\hline Endosulfan & 24 & 0.0145 & $0.0131-0.0139$ \\
Endosulfan & 48 & 0.0135 & $0.0131-0.0139$ \\
& 96 & 0.0127 & $0.0124-0.0129$ \\
Klorpirifos & 24 & 0.275 & $0.252-0.293$ \\
Chlorpyrifos & 48 & 0.260 & $0.241-0.281$ \\
& 96 & 0.245 & $0.225-0.267$ \\
\hline
\end{tabular}

akuatik ini dinyatakan dalam $\mathrm{mg} / \mathrm{L}$ bahan aktif insektisida. Berdasarkan dosis pemakaiannya untuk penanggulangan hama tanaman Bathe et al. (1974) mengatagorikan pestisida dengan nilai $\mathrm{LC}_{50}<0,5 \mathrm{mg} /$ $\mathrm{L}$ (bahan aktif) sebagai pestisida yang berdaya racun sangat tinggi pada ikan. Dengan demikian maka insektisida endosulfan dan klorpirifos tergolong jenis insektisida yang berdaya racun sangat tinggi pada ikan, khususnya ikan nila.

Nilai-nilai LC $_{50}$ insektisida klorpirifos untuk waktu dedah 24, 48, dan 96 jam tidak berbeda nyata $(P<0,05)$. Nilai-nilai $L_{50}$ insektisida endosulfan pada waktu dedah 24 dan 48 jam juga tidak berbeda nyata $(P>0,05)$, akan tetapi berbeda nyata dengan nilai $L_{50}$ untuk waktu dedah 96 jam.

Data hasil pengujian toksisitas letal insektisida endosulfan dan klorpirifos di atas sesuai dengan data yang diperoleh Koesoemadinata (2000) yang melaporkan bahwa $\mathrm{LC}_{50}-96 \mathrm{jam}$ untuk kedua insektisida tersebut terhadap benih ikan nila yang berukuran relatif lebih kecil (bobot rata-rata 1,7 g), masing-masing adalah $0,0095 \mathrm{mg} / \mathrm{L}$ dan $0,151 \mathrm{mg} / \mathrm{L}$. Hasil penelitian Yudha (1999) menunjukkan bahwa nilai LC ${ }_{50}$-96jam endosulfan untuk ikan lele dumbo (Clarias gariepinus) tidak jauh berbeda, yakni 0,01713mg/L. Tingginya daya racun disebabkan antara lain karena proses metabolisme senyawa dalam tubuh ikan ini hanya mampu
Pengaruh konsentrasi subletal insektisida endosulfan dan klorpirifos terhadap laju pertumbuhan spesifik benih ikan nila pada jangka waktu satu bulan, dapat dilihat pada Tabel 2 dan Tabel 3.

Laju pertumbuhan spesifik individu benih ikan nila menurun sejalan dengan semakin tingginya perlakuan konsentrasi subletal kedua insektisida. Hasil analisis statistik menunjukkan bahwa laju pertumbuhan benih ikan nila di antara perlakuan insektisida dan kontrol berbeda nyata $(P<0,05)$. Pengaruh jangka panjang konsentrasi subletal kedua insektisida tersebut ternyata dapat menyebabkan kerusakan morfologis dan gangguan fisiologis terhadap ikan. (Holcombe et al.,1982). Pengaruh ini dapat berakibat fatal pada sintasan ikan, karena akan berkurangnya stamina dan kemampuan ikan untuk mencari makanan. Di samping itu pertumbuhan yang tidak normal dapat mengakibatkan menurunnya produktivitas dan kualitas benih ikan yang dihasilkan oleh para petani pembenih dan pendeder ikan.

Hasil percobaan menunjukkan bahwa endosulfan dan klorpirifos pada konsentrasi subletal masingmasing $0,001 \mathrm{mg} / \mathrm{L}$ dan $0,05 \mathrm{mg} / \mathrm{L}$; secara nyata dapat mengganggu pertumbuhan benih ikan nila. Dari data tersebut dapat disyaratkan bahwa endosulfan berpengaruh sedikitnya dua kali lebih buruk terhadap pertumbuhan ikan dibandingkan dengan klorpirifos. 
Tabel 2. Pengaruh konsentrasi subletal insektisida endosulfan pada laju pertumbuhan spesifik benih ikan nila (Oreochromis niloticus)

Table 2. The effects of sublethal concentrations of the insecticides endosulfan on the specific growth rate of nile tilapia (Oreochromis niloticus)

\begin{tabular}{cccc}
$\begin{array}{c}\text { Konsentrasi (mg/L) } \\
\text { Concentration (mg/L) }\end{array}$ & $\begin{array}{c}\text { Bobot awal (g) } \\
\text { Initial weight }(\mathbf{g})\end{array}$ & $\begin{array}{c}\text { Bobot akhir (g) } \\
\text { Final weight }(\mathbf{g})\end{array}$ & $\begin{array}{c}\text { Laju pertumbuhan spesifik (\%) } \\
\text { Specific growth (\%) }\end{array}$ \\
\hline 0 & 1.43 & 2.12 & $1.31^{\mathrm{a}}$ \\
0.001 & 1.56 & 2.12 & $1.02^{\mathrm{b}}$ \\
0.005 & 1.41 & 1.95 & $1.03^{\mathrm{b}}$ \\
0.010 & 1.46 & 1.96 & $0.98^{\mathrm{b}}$ \\
\hline
\end{tabular}

Angka rata-rata dalam lajur dengan notasi huruf yang sama tidak berbeda nyata $(P>0,05)$

Means followed by a common letter are not significantly different $(P>0.05)$

Tabel 3. Pengaruh konsentrasi subletal insektisida dan klorpirifos pada laju pertumbuhan spesifik benih ikan nila (Oreochromis niloticus)

Table 3. The effects of sublethal concentrations of the insecticides chlorpyrifos on the specific growth rate of nile tilapia (Oreochromis niloticus)

\begin{tabular}{cccc}
$\begin{array}{c}\text { Konsentrasi (mg/L) } \\
\text { Concentration }(\mathbf{m g} / \mathrm{L})\end{array}$ & $\begin{array}{c}\text { Bobot awal (g) } \\
\text { Initial weight (g) }\end{array}$ & $\begin{array}{c}\text { Bobot akhir (g) } \\
\text { Final weight }(\mathbf{g})\end{array}$ & $\begin{array}{c}\text { Laju pertumbuhan spesifik (\%) } \\
\text { Specific growth (\%) }\end{array}$ \\
\hline 0 & 3.57 & 5.02 & $1.14^{\mathrm{a}}$ \\
0.05 & 3.48 & 4.77 & $1.05^{\mathrm{b}}$ \\
0.1 & 3.5 & 4.61 & $0.92^{\mathrm{b}}$ \\
0.15 & 3.49 & 4.58 & $0.90^{\mathrm{b}}$ \\
\hline
\end{tabular}

Angka rata-rata dalam lajur dengan notasi huruf yang sama tidak berbeda nyata $(P>0,05)$

Means followed by a common letter are not significantly different $(P>0.05)$

Namun seperti terungkap di atas', klorpirifos kemungkinan memiliki bioaktivitas yang lebih persisten dibandingkan dengan endosulfan, sehingga pencemaran air oleh kedua jenis insektisida tersebut berpotensi sama buruk terhadap perikanan air tawar.

Hasil penentuan tingkat absorbsi insektisida endosulfan dan klorpirifos masing-masing tertera pada Tabel 4 dan Tabel 5. Data dalam tabel tersebut menunjukkan bahwa tingkat absorbsi kedua insektisida dalam tubuh ikan nila relatif tidak berbeda. Namun demikian konsentrasi insektisida klorpirifos yang diuji adalah dua kali lipat tingkat konsentrasi insektisida endosulfan, sehingga kemungkinan insektisida yang terakhir ini lebih bersifat akumulatif. Menurut Smith et al. (1966), klorpirifos dapat terabsorbsi dengan cepat oleh air akan tetapi sebaliknya proses absorbsi senyawa ini oleh tubuh ikan agak lambat. Barron \& Woodburn (1995) menyatakan bahwa klorpirifos dalam lingkungan terestrial maupun akuatik dapat terdegradasi melalui proses biotik dan abiotik. Proses degradasi ini terutama terjadi karena pemisahan ikatan ester fosforotiat yang membentuk 3,5,6-trikloro2-piridinol (TCP), yang selanjutnya dapat terdegradasi melalui proses fotolisis (Dilling et al., 1984).

Tabel 4. Tingkat residu ikan nila pada percobaan penentuan tingkat absorpsi insektisida klorpirifos

Table 4. Residues levels in the nile tilapia in the absorption rate experiment of the insecticide chlorpyrifos

Konsentrasi nominal (mg/L) Residu dalam ikan (mg/kg) Tingkat absorbsi (\%) Nominal concentration (mg/L) Residu infish ( $\mathrm{mg} / \mathrm{kg}$ ) Absorbtion rate (\%)

\begin{tabular}{ccc}
\hline 0.05 & 0.0047 & 9 \\
0.1 & 0.0227 & 22 \\
0.15 & 0.0316 & 21 \\
\hline
\end{tabular}


Tabel 5. Tingkat residu pada ikan nila pada percobaan penentuan tingkat absorbsi insektisida endosulfan Table 5. Residues levels in the nile tilapia in the absorbtion rate experiment of the insecticide endosulfan

\begin{tabular}{ccc}
$\begin{array}{c}\text { Konsentrasi nominal (mg/L) } \\
\text { Nominal concentration (mg/L) }\end{array}$ & $\begin{array}{c}\text { Residu dalam ikan (mg/kg) } \\
\text { Residu in fish (mg/kg) }\end{array}$ & $\begin{array}{c}\text { Tingkat absorbsi (\%) } \\
\text { Absorbtion rate (\%) }\end{array}$ \\
\hline 0.001 & 0.0001 & 10 \\
0.005 & 0.00111 & 22 \\
0.01 & 0.00201 & 20 \\
\hline
\end{tabular}

\section{KESIMPULAN}

* Insektisida endosulfan dan klorpirifos berdaya racun akut sangat tinggi pada ikan nila

* Pada konsentrasi subletal masing-masing 0,001mg/ $L$ dan $0,05 \mathrm{mg} / \mathrm{L}$. insektisida endosulfan dan klorpirifos telah dapat menghambat laju pertumbuhan ikan nila.

* Pada tingkat konsentrasi subletal, insektisida endosulfan dan klorpirifos (masing-masing $0,005 \mathrm{mg} /$ $\mathrm{L}$ dan $0,1 \mathrm{mg} / \mathrm{L}$ ) dapat terakumulasi dalam tubuh ikan nila dengan tingkat absorbsi $22 \%$ dari konsentrasi nominal insektisida dalam air pada jangka waktu satu bulan.

\section{SARAN}

* Insektisida endosulfan dan klorpirifos disarankan untuk tidak digunakan di wilayah perairan perikanan budi daya air tawar untuk menghindari terjadinya pencemaran air oleh kedua senyawa bahan aktif insektisida tersebut.

\section{DAFTAR PUSTAKA}

Ananda S., P. Mohana, D. Rao, and Murty, A.S.1981. Toxicity of endosulfan to the freshwater fish Cirrhinus mrigal. Bull. Environ. Contam. Toxicol. p. 27:850.

Anonymus.1980. Ambient Water Quality Criteria for Endosulfan. EPA 440/5/ 80046. Office of water Regulation and standard criteria Division. EPA. Washington.

Barron,M.G. and K.B. Woodburn.1995.Ecotoxicology of Chlorpyrifos. Reviews of Environmental Contamination and Toxicology. Vol. 144. 1995. Springer-Verlag New York, Inc. 93 pp.

Bathe, R, K. Sachsee, L. Ullman, W.D. Hormann, F. Zak, and R. Hess. 1974. The evaluation of fish toxicity in the laboratory. Excepta Medica XVI: 113--124.

Dilling, W.L, L.C. Lickly, T.D. Lickly, P.C. Murphy, and R.L. McKellar.1984. Organo photochemistry 19. Quantum yield for 0,0-diethyl 0-(3,5,6-trichloro-2 pyridyl) phosphorothioate (chlorpyrifos) and 3,5,6-trichloropyridinol in aqueous solutions and their environmental photo trans-formation rates. Environ Sci. Technol. 18: 540--543

El-Rifai, A, F.D. Fouad, M.F. Abdel-Latief, and A.K.E. Imam.1976. Toxicity of three insecticides to two species of fish. Int. Pest Control. 18: 4--8.
EPA.1980. Ambient Water Quality Criteria for Endosulfan. EPA 440/5-80046. Office of water regulation and standard criteria and standards division. EPA, Washington.

FAO.1987. Manual of methods in aquatic environment research Part 10: Short-term static bioassay. FAO Fisheries Technical Paper 247. 62 pp.

Finney,D.J. 1971. Probit Analysis. $3^{\text {rd }}$ edition. Carnbridge at the University Press. 333 pp.

Gorbach,S.,R.Haaring,W.Knauf, and H.J.Werner.1971a. Residue analysis in the water system of East Java (River Brantas, ponds, sea water) after continued large scale application of thiodan in rice. Bull. Environ. Contamin. Toxicol. 6(3): 193--199.

1971b. Residue analysis and biotests in rice fields of East Java treated with Thiodan. Bull. Environ. Contamin. Toxicol. 6(3): 193--199

Holcombe, G.W., Phipps, G.L, and Tanner, D.K.1982. The acute toxicity of Kelthane, Dursban, disulfoton, pydrin, and permethrin to fathead minnows and rainbow trout. Environ. Pollut. 29: 167.

Koesoemadinata, S.1980. Pesticides as a major constraint to integrated agriculture-aquaculture farming system. ICLARM Conference Proceeding 4: 45--52.

2000. Toksisitas akut formulasi insektisida endosulfan, klorpirifos dan klorfluazuron pada tiga jenis ikan air tawar dan udang galah. J. Penel. Perikanan Ind. 34 (3-4): 35--43.

Macek, K.J., C. Hutchinson, and O.B. Cope. 1969. The effects of temperature on the susceptibility of bluegills and rainbow trout to selected pesticides. Bull. Environ. Contam. Toxicol. 4: 174.

Murty, A.S and D.A. Priyamanvada.1982. The effects of endosulfan and its isomer on tissue protein, glycogen and lipids in the fish Channa punctata. Pestic. Biochem. Physiol. 12: 280.

OECD. 1992. OECD Guide Lines for Testing of Chemicals No. 203. Fish, acute toxicity test adopted 17.07.92. 4 pp.

Rao, D.M.R, A.P. Devi, and A.S. Murty. 1981. Toxicity and metobolism of endosulfan and its effects on oxygen consumption and total nitrogen excretion of the fish Macronagthus aculentum. Pestic.Biochem. Physiol. 15: $282--284$

Spacie, A. and Hamelink, J.L. 1985. Bioaccumulation. In: Fundamentals of Aquatic Toxicology. Rand, G.M and Petrocelli, S.R (Eds.). Hemisphere Publishing. p. 495--526. 
Smith, G.N, B.S. Watson, dan F.S. Foscher. 1966. The metabolism of $\left[{ }^{14} \mathrm{C}\right]$ 0,0-Diethyl 0-(3,5,6-trichloro-2pyridyl) phosphorothioate (Dursban) in fish. $J$. Econom. Entomol. 59: 1.464-1.475.
Yudha, I. G. 1999. Toksisitas Akut dan Pengaruh Subletal Endosulfan terhadap Pertumbuhan dan Kondisi Hematologis Ikan Lele Dumbo (Clarias gariepinus). Tesis Program Pascasarjana, Institut Pertanian Bogor. 